\title{
THE CLEAN AND HEALTHY LIFE BEHAVIOR (PHBS) AMONG ELEMENTARY SCHOOL STUDENTS IN EAST KURIPAN, WEST NUSA TENGGARA PROVINCE
}

\author{
Dyah Suryani, ${ }^{1}$ Maretalinia, ${ }^{2}$ Suyitno, ${ }^{2}$ Baiq Rini Oktina, ${ }^{1}$ \\ Elvi Juliansyah, ${ }^{2}$ Ria Damayanti, ${ }^{2}$ Aris Yulianto ${ }^{3}$ \\ ${ }^{1}$ Faculty of Public Health, Ahmad Dahlan University, Yogyakarta \\ ${ }^{2}$ Kapuas Raya College of Health Science, Sintang Regency, West Kalimantan \\ ${ }^{3}$ National Institute of Health Research Development, Ministry of Health Indonesia
}

\begin{abstract}
School-age is a golden period to instill the values of clean and healthy life behavior (PHBS), so it has the potential as an agent of change to promote within the school, family and community. The function of the school is also a place of learning that can be a threat of disease transmission if not managed properly. Besides, school-age for children is also a vulnerable period for various diseases. The aim of this study was to determine the association between knowledge, attitude and role of teacher with the implementation of PHBS in the school. This study used observational quantitative research by using a cross-sectional approach. The research subjects were 58 students in fourth and fifth grade from elementary school number 1 East Kuripan West Lombok which selected by using total sampling. That school was selected because it has the lowest scope in terms of implementation of PHBS. The instrument used was a questionnaire in the checklist form which consisted of 19 questions about knowledge, 15 questions about attitude, 13 questions about the role of teacher, and 11 questions about the implementation of PHBS. Each variable was categorized into good category if the correct answers was covered $\geq 70 \%$ out of total score, and vice versa. Data analysis performed by Chi-square. The results of the bivariate analysis revealed that knowledge and attitude were significantly associated with implementation of PHBS behavior. The role of the teacher did not have any association with implementation of PHBS among fourth and fifth grade elementary school students' number 1 East Kuripan. It can be concluded that the implementation of PHBS in Elementary School Number 1 was influenced by student's knowledge and attitude.
\end{abstract}

Keywords: Knowledge, attitudes, the role of teachers, clean and healthy life behavior.

\begin{abstract}
ABSTRAK
Usia sekolah merupakan masa keemasan untuk menanamkan nilai-nilai perilaku hidup bersih dan sehat (PHBS) sehingga berpotensi sebagai agen perubahan untuk mempromosikan PHBS, baik dilingkungan sekolah, keluarga dan masyarakat. Sekolah selain berfungsi sebagai tempat pembelajaran juga dapat menjadi ancaman penularan penyakit jika tidak dikelola dengan baik. Selain itu, usia sekolah bagi anak juga merupakan masa rawan terserang berbagai penyakit. Tujuan penelitian ini adalah untuk mengetahui hubungan antara tingkat pengetahuan, sikap, dan peran guru terhadap penerapan PHBS sekolah. Jenis penelitian ini adalah kuantitatif dengan metode observasional dengan pendekatan cross-sectional. Subjek penelitian adalah siswa kelas IV dan V di SD Negeri 1 Kuripan Timur Lombok Barat yang berjumlah 58 siswa yang dipilih secara total sampling. SD Negeri 1 Kuripan Timur Lombok Barat merupakan sekolah yang cakupan PHBS nya paling rendah. Instrumen penelitian yaitu kuesioner dalam bentuk lembar checklist yang terdiri dari 19 pertanyaan tentang pengetahuan, 15 pertanyaan tentang sikap, 13 pertanyaan tentang peran guru, dan 11 pertanyaan tentang PHBS. Masing-masing variable dikategorikan baik jika jawaban benar $\geq 70 \%$ dari skor total, dan sebaliknya. Analisis data menggunakan uji Chi-square. Hasil analisis bivariat menunjukkan ada hubungan antara tingkat pengetahuan dan sikap dengan PHBS dan tidak terdapat hubungan antara peran guru dengan PHBS pada siswa di SD Negeri 1 Kuripan Timur Lombok Barat. Dapat disimpulkan bahwa penerapan PHBS Sekolah di SD Negeri 1 Kuripan Timur dipengearuhi oleh faktor pengetahuan dan sikap siswa tentang PHBS sekolah.
\end{abstract}

Kata Kunci: Pengetahuan, sikap, peran guru, perilaku hidup bersih dan sehat (PHBS).

\footnotetext{
${ }^{1}$ Correspondece Address: Dyah Suryani, Faculty of Public Health, Ahmad Dahlan University, Yogyakarta Email: dyahsuryani.ds@gmail.com
} 


\section{INTRODUCTION}

The proportion of children aged 0 to 17 years in Indonesia takes $30 \%$ out of the total population, namely $237,556,363$. Among that, $25,486,506$ of them attended the elementary school in 148,244 schools. As large as important, children in school-age is a capital asset for country development which should be trained, improved, and protected in term of their health status. It is a golden period to initiate the clean and healthy life behavior (PHBS) so they could be the agent of change and health promotor for their own family, environment, school, and community. In terms of the function of the school as a learning facility, it still has the chance to transmit the disease between children, teachers, visitors, or others. To prevent it, the integrated school management is needed to implement the promotion and prevention approach. Furthermore, school-age is also a vulnerable period for various diseases. ${ }^{1}$

Nowadays, the lower practice of clean and healthy life behavior remains occurred among children and families. In 2010, the development index revealed that the national percentage of PHBS practices was only $35.7 \%$ while the percentage of handwashing with soap practices was only 24.5\%. According to basic health research (RISKESDAS) 2018, the percentage of population aged 10 years or above who behaved correctly in defecation was up to $82.6 \%$ and proper handwashing behavior was $49.8 \% .^{2}$ The practice of unclean and unhealthy life behavior might be the cause of many people experienced health problems, including in school age. The health behavior in schoolaged is related to the knowledge of personal hygiene, and the environment (physically, psychologically, biologically). The counseling regarding clean and healthy life behavior is important to all populations, particularly, for children in school-age who had less knowledge about health. ${ }^{3}$

Regarding the health screening data involved in the $1^{\text {st }}$ grade of elementary school/Islamic elementary school in West Nusa Tenggara Province in 2017, it was found the $90.54 \%$ of them did not access the health service properly. Furthermore, all districts and cities in that province did not provide the health screening service for a 1st-grade student of elementary school even though the dental health service activities in the School Dental Health Effort (UKGS - Usaha Kesehatan Gigi Sekolah) program on the dental health status of elementary school has not been satisfactory. Besides, to examine the student's dental, the UKGS program is also oriented towards mass and individual preventive and promotive activities such as joint the toothbrush demonstrations. It was conducted by elementary school students in 2016 in West Nusa Tenggara Province and was only reported by 7 districts. In West Lombok Regency, there is 444 elementary school but less than half of them were participating in the toothbrush program. ${ }^{4}$

The preliminary research was conducted on February 25 , 2019 in Elementary School 
Number 1, West Kurip, Kuripan District, West Lombok where located far away from the city so there was no counseling that could be conducted particularly about clean and healthy life behavior. 11 out of 15 respondents had long nails and dressed less neatly and some said that they did not wash hands with soap before and after eating. Nail and neat examinations are still rarely done, usually check once a week on Monday. Cleanliness and neatness of students are rarely noticed by the teacher so it is the must. Besides, the observation results revealed that the availability of clean water, bathrooms, and supporting facilities remains the problem to support the practice of clean and healthy life behavior. The aim of this study was to determine the association between knowledge, attitude and role of teacher with the implementation of PHBS.

\section{METHOD}

The study location of this study is at elementary school number 1 East Kuripan, Kuripan District, West Lombok Regency, West Nusa Tenggara Province and employed students in IV and $\mathrm{V}$ grade, precisely at TGH. Muhammad Arif Rarangan street, East Kuripan Village, Kuripan District, West Lombok Regency, West Nusa Tenggara Province. East Kuripan Public Elementary School was established in 1910 in a rural area, the status is a government school, the accreditation is $\mathrm{B}$, learning activities is in the morning, has a self-owned school building, has the distance to the subdistrict center around $1 \mathrm{~km}$.

This study was examined by a quantitative approach with observational methods. This crosssectional study was employed the Elementary School students Number 1 East Kuripan that drawn the independent and dependent variables in one time period. The school selected based on preliminary research which revealed that Elementary School Number 1 East Kuripan had a low scope in terms of The School Clean and Healthy Life Behavior (PHBS Sekolah). The population used in this study were all students in grades IV and V in East Kuripan 1 Elementary School, a total of 58 students. The sample was selected in those 2 grades due to their capability to answer the questionnaire and the time availability. Data collection techniques using total sampling, this study uses instruments and measuring tools in the form of a questionnaire in the form of a checklist sheet which consisted of 19 questions about knowledge, 15 questions about attitude, 13 questions about the role of teacher, and 11 questions about the implementation of PHBS behavior.

The variable of knowledge was determined by using questions related to clean and healthy life behavior, the washing hand behavior, self-sanitation, exercise, eradication of mosquito larvae, measure height and weight, negative effect of smoking, the habit of taking out the trash, food hygiene in the canteen, and using the toilet properly. The variable of attitude was determined by using questions related to self-sanitation, hand washing behavior, the habit of taking out the trash, food hygiene in the canteen, eradication of mosquito larvae, negative effect of smoking, using the 
toilet properly, measure height and weight, and exercise. The variable of implementation of PHBS behavior was determined by using questions related to the washing hand behavior, the habit of taking out the trash, using the toilet properly, measure height and weight, food hygiene in the canteen, and self-sanitation. The variable of the role of teacher was determined by using questions related to the habit of taking out the trash, negative effect of smoking, self-sanitation, measure height and weight, using the toilet properly, the washing hand behavior, eradication of mosquito larvae, food hygiene in the canteen, and exercise. Each variable was categorized into good category if the correct answers covered more than or equal $70 \%$ out of all question, and the bad category if the correct answers covered less than $70 \%$ out of all questions. The data analysis was done by using the Chi-Square Test statistic test.

\section{RESULTS}

\section{General Description Respondents}

Characteristics of respondents based on gender and age in students at Elementary School Number 1 East Kuripan, Kuripan District, West Lombok, can be seen in the following table:

Table 1. Characteristics of Respondents by Gender and Age in IV and V grade Students in
\begin{tabular}{ccc} 
Elementary School Number & Last Kuripan in 2019 $(\mathbf{n = 5 8})$ \\
\hline Variables & $\mathbf{n}$ & Percentage (\%) \\
\hline Sex & 25 & \\
Male & 33 & 43,1 \\
Female & & 56.9 \\
Age (years) & 16 & 27.6 \\
10 & 29 & 50.0 \\
11 & 13 & 22.4 \\
12 & & \\
\hline
\end{tabular}

Table 1 shows that female respondents had a higher proportion of 33 people (56.9\%) compared to male respondents. Whereas the age characteristics showed that respondents at the age of 11 years were the highest age, 29 people with a percentage of $50 \%$.

\section{Univariate Analysis}

Univariate analysis is used to find a general description of each research variable. The univariate analysis produces frequency distributions and percentages of each variable. 
Table 2. Frequency Distribution of Respondents Based on Knowledge, Attitudes and the Role of Teachers, and Behavior

\begin{tabular}{|c|c|c|}
\hline Variables & $\mathbf{n}$ & Percentage (\%) \\
\hline \multicolumn{3}{|l|}{ Knowledge } \\
\hline Bad & 27 & 46.6 \\
\hline Good & 31 & 53.4 \\
\hline \multicolumn{3}{|l|}{ Median $=3, \mathrm{QD}=1, \operatorname{Min}=0, \operatorname{Max}=4$} \\
\hline \multicolumn{3}{|l|}{ Attitude } \\
\hline Bad & 30 & 51.8 \\
\hline Good & 28 & 48.2 \\
\hline \multicolumn{3}{|c|}{ Median $=8, Q D=3.5, \operatorname{Min}=0, \operatorname{Max}=10$} \\
\hline \multicolumn{3}{|c|}{ The role of the teacher } \\
\hline Bad & 21 & 36.2 \\
\hline Good & 37 & 63.8 \\
\hline \multicolumn{3}{|l|}{ Median $=5, Q D=1.1, \operatorname{Min}=1, \operatorname{Max}=7$} \\
\hline \multicolumn{3}{|l|}{ Behavior } \\
\hline Bad & 31 & 53.4 \\
\hline Good & 27 & 46.6 \\
\hline Median $=3, \mathrm{QD}=2, \operatorname{Min}=1, \operatorname{Max}=$ & & \\
\hline
\end{tabular}

Table 2 shows that according to knowledge, more than half of the respondents had good knowledge in terms of clean and healthy life behavior. Opposite from the knowledge, the attitude of students showed that more than half of them did not have a good attitude. Furthermore, the role of the teacher took a majority in the implementation of clean and healthy life behavior. In general, clean and healthy life behavior, more than half of them practice bad behavior. The relationship between knowledge, attitudes, and the role of teacher with implementation of clean and healthy life behavior by using Chi-square used a significance level of $\mathrm{p}<0.05$.

Table 3. Chi-Square Test Results between Knowledge, Attitude and Role of Teachers with Clean and Healthy Life Behavior in IV and V grade Students in Elementary School Number 1 East Kuripan

\begin{tabular}{llllll}
\hline \multirow{2}{*}{ Variables } & \multicolumn{2}{l}{ Clean and Healthy Life Behavior } & \multirow{2}{*}{ Total } & \multirow{2}{*}{ P-Value } & \multirow{2}{*}{ RP (95\% CI) } \\
\cline { 2 - 3 } & \multicolumn{1}{l}{ Bad $(\mathrm{n})$} & Good $(\mathrm{n})$ & & & \\
\hline Knowledge & $19(32.8 \%)$ & $8(13.8 \%)$ & $27(48.6 \%)$ & 0.032 & $1.82(1.09-3.01)$ \\
Bad & $12(20.7 \%)$ & $19(32.8 \%)$ & $31(53.4 \%)$ & & \\
Good & & & & \\
Attitude & $21(36.2 \%)$ & $9(15.5 \%)$ & $30(51.7 \%)$ & 0.019 & $1.96(1.13-3.39)$ \\
Bad & $10(17.2 \%)$ & $18(31.0 \%)$ & $28(48.3 \%)$ & & \\
Good & & & & \\
The role of teacher & $12(20.7 \%)$ & $9(15.5 \%)$ & $21(36.2 \%)$ & 0.880 & $1.11(0.69-1.80)$ \\
Bad & $19(32.8 \%)$ & $18(31.0 \%)$ & $37(63.8 \%)$ & & \\
Good & &
\end{tabular}

Table 3 shows the results of the analysis of the relationship between the level of knowledge, attitudes and the role of the teacher with clean and healthy life behavior in students using the ChiSquare Test. From 58 respondents, for the level of knowledge, it is known that respondents who have a good level of knowledge and good behavior are 19 students (32.8\%), respondents who have a bad level of knowledge and bad behavior are 19 students (32.8\%), respondents who have good knowledge but clean and healthy life behaviors are not good as many as 12 students (20.7\%) and 
respondents who have bad knowledge but healthy and good living behaviors are as many as 8 students $(13.8 \%)$. Statistical test results obtained $p$-value $=0.032$, where the value of $p$-value < 0.05 which means there is a relationship between knowledge and clean and healthy life behavior in students at Elementary School Number 1 East Kuripan, Kuripan District, West Lombok Regency. For attitude variables, it is known that respondents who have a good attitude in term of clean and healthy life behavior and good behavior are 18 students (31.0\%), respondents who have a bad attitude and bad behavior are 21 students $(36.2 \%)$, respondents who have a good attitude but clean and healthy life behavior was not good as many as 10 students (17.2\%) and respondents who have a bad attitude in but clean and healthy life behavior good as many as 9 students (15.5\%).

Statistical test results obtained $\mathrm{p}$-value $=0.019$, where the value of $\mathrm{p}$-value $<0.05$ means that there was a relationship between attitudes with clean and healthy life behavior in students at Elementary School Number 1 East Kuripan, Kuripan District, West Lombok Regency, NTB. In the role of teacher variable, it is known that the respondents in the good category and good behavior were 18 students $(31.0 \%)$, respondents in the bad category and bad behavior were 12 students $(20.7 \%)$, respondents in the good category but the behavior of clean and healthy living not well as much 19 students (32.8\%) and respondents in the category of not good but good hygiene and good behavior as many as 9 students (15.5\%). The value of the p-value is 0.880 which is the value of $p$ value $>0.05$ so the hypothesis was rejected. Therefore, it can be concluded that there is no relationship between the role of the teacher with clean and healthy life behavior in students in Elementary School Number 1 East Kuripan, Kuripan District, West Lombok Regency.

\section{DISCUSSION}

This study was found that most of the respondents had good knowledge levels of 31 respondents with a percentage of $53,4 \%$ Statistical test results obtained values $(\mathrm{p}=0.032, \mathrm{CI}=$ 1.096-3.015), where the value of $p$-value $<0.05$ so that it is statistically significant, which means there is a relationship between knowledge and clean and healthy life behavior for students at Elementary School Number 1 East Kuripan, Kuripan District, West Lombok Regency. The value of Risk Prevalence (RP) obtained is 1,818 which means that those who had bad knowledge about PHBS were 1.818 times more likely to do not implement the PHBS.

Student's knowledge about PHBS in Elementary School Number 1 East Kuripan Kuripan District West Lombok Regency can be concluded to be lacking when viewed from the results obtained, it can be caused by several factors. It can be including supporting facilities and infrastructure that is still lacking and has never been conducted counseling, especially related with clean and healthy life behavior in school. Knowledge is one of the factors forming behavior. High or low knowledge can be influenced by the learning process and the effect of environment. Knowledge of the concept of a clean and healthy life has an impact on individual behavior and 
affects the health status of individuals.

Behavior is formed on 3 main factors, namely predisposing factors, enabling factors, and reinforcing factors. Predisposing factors include community knowledge and attitudes, community traditions and beliefs on related matters, the value system adopted by the community, education level, and socioeconomic level. Enabling factors include the availability of facilities and infrastructure for the community. The attitude and behavior of respected figures become reinforcing factors for the formation of behavior. ${ }^{5}$ There are some techniques to increase the knowledge including seminar, discussion, and props and it is a very fixed determinant to increase the implementation of clean and healthy life behavior. ${ }^{6,7}$ The importance of counseling was found a significant factor to increase knowledge in terms of clean and healthy life behavior. ${ }^{8}$

This research is supported by previous research in North Tapanuli, Selemadeg, Pati, Jember, Makassar, and Banyumanik which states that there was a relationship between students' knowledge about clean and healthy behavior and implementation of clean and healthy life behavior. $^{9-14}$ This study is also in line with previous research which shows that there is a relationship between knowledge and implementation of clean and healthy life behavior in 112 Elementary School Students in Manado with a p-value $=0.000$ which less than 0.05 so that Ho is rejected, the RP obtained by 31.42 means that students having bad knowledge has 31.42 times more likely to do not implement the PHBS. ${ }^{15}$ Thus, it supports this research where indirectly it can be concluded that students who have bad knowledge have a greater chance of behaving poorly towards the implementation of clean and healthy life behavior. The research conducted in Tikala Manado also found that knowledge of students seems very good in terms of the practice of clean and healthy life behavior. ${ }^{16}$ However, the implementation of clean and healthy life behavior in Pekanbaru showed the medium category even though the knowledge seemed good. ${ }^{17}$

The study employed the street children in Yogyakarta found the opposite result which did not find any relationship between knowledge and implementation of clean and healthy life behavior. ${ }^{18}$ Besides the knowledge of children, the parent's knowledge is also important which was revealed that the strong significance in Malang. ${ }^{19}$ The increasing knowledge will lead to the implementation of clean and healthy life behavior in Wonodadi and Sangihe. ${ }^{20,21}$ The study in Padang found low knowledge in terms of implementation of clean and healthy life behavior especially for the use of sanitary latrines and healthier. ${ }^{22}$ Education is needed to elevate the implementation of clean and healthy life behavior. ${ }^{23}$

Most of the respondents had a bad attitude in term of clean and healthy life behavior, as many as 30 respondents with a percentage of $51.7 \%$. Statistical test results obtained values (pvalue $=0.019, \mathrm{CI}=1,132-3,395)$, where the value of $\mathrm{p}$-value $<0.05$ so that it is statistically significant, which means there is a relationship between attitude and clean and healthy life behavior for students at Elementary School Number 1 East Kuripan, Kuripan District, West Lombok 
Regency, West Nusa Tenggara. The value of Risk Prevalence (RP) obtained is 1.960, it means that students who have bad attitudes have 1.960 times more likely to do not implement the clean and healthy life behavior.

From the results of research students' attitudes toward the implementation of clean and healthy life behavior in Elementary School Number 1 East Kuripan, Kuripan District West Lombok Regency, it remains in the inadequate category that can be caused by unsupported facilities and infrastructure, lack of awareness and understanding of clean and healthy behavior.

Factors that influence attitudes are personal experience, the influence of others who are considered important, the influence of culture, mass media, educational institutions, and religious institutions as well as emotional factors. It is expected that the higher education, the higher the knowledge gained so that it is expected that if the good knowledge will affect a good attitude as well. In addition to the education factor, there is also a source of information. It needs to be given counseling and health promotion as the basis for students about clean and healthy life behavior to further enhance changes in attitudes for the better to create a healthy environment both within the school and in the family environment. ${ }^{24}$ The attitude in terms of personal hygiene also significantly associated with clean and healthy life behavior practices in Malang. ${ }^{25}$

This study is in line with previous research in Manado, Yogyakarta, Pati, Makassar, and Banyumanik which states that there is a relationship between attitudes with clean and healthy life behavior in students. ${ }^{11,12,14,16,26}$ This is also supported by previous research in Ireland. This study found that attitudes and lifestyles can increase the value of life expectations relating to personal health in general, which is positive, in this case, a clean and healthy life behavior. ${ }^{27}$ Thus, it supports this research where indirectly it can be concluded that students who have bad attitudes have a greater chance of behaving poorly towards the implementation of clean and healthy life behavior. However, the study employed the street children in Yogyakarta did not find any association between attitude and implementation of clean and healthy life behavior. ${ }^{18}$ In terms of the risk of unpracticed of clean and healthy life behavior, the study in Boyolali and North Banjarbaru found a strong association between clean and healthy life behavior and diarrhea prevalence. ${ }^{28,29}$

The majority of teacher's role in term of clean and healthy life behavior, in both good categories by 37 respondents with a percentage of $63.8 \%$. The statistical test results obtained pvalue $>0.05$ so that it is not statistically significant, which means there is no relationship between the role of the teacher and clean and healthy living behaviors in students at Elementary School Number 1 East Kuripan, Kuripan District, West Lombok Regency. In terms of practices of clean and healthy life behavior among students of beginner school, it was revealed that only $18.75 \%$ of them did good practice. ${ }^{30}$

The role of the teacher in Elementary School Number 1 East Kuripan is still in the good 
category, it can be seen from the results of the study that there is no relationship between the role of the teacher with clean and healthy life behaviors among students. However, several factors do not support their formation well. Among them, there is no information available for educating student how to practice PHBS and there is no ban for student to buy snack outside the school canteen.

Three factors cause a person to conduct health behaviors as explained previously, here the role of the teacher in the implementation of clean and healthy life behavior on students is included in the reinforcing factors, namely the attitude and role of the teacher in the application of clean and healthy life in students at school which students believe to be role models so that students will imitate the attitudes and behavior of a teacher. ${ }^{31}$ This study is opposite with previous research in Balai Karimun which states there is a significant relationship between the role of teachers with clean and healthy life behavior with a p-value of 0,00 or smaller than $0.05 .^{32,33}$ This study did not found any role of teacher in terms of implementation of PHBS among students.

\section{CONCLUSION}

The implementation of clean and healthy life behavior in elementary school student grade IV and V significantly was affected by knowledge and attitude. However, the role of the teacher was not found any association with the implementation of clean and healthy life behavior. Based on the research results obtained, there are a number of suggestions that need to be taken into consideration for related parties, including the following:Elementary School Number 1 East Kuripan, It is expected that educational institutions will make greater efforts to improve the quality of sanitation facilities in the school, which include provide the clean water sources, rubbish bins, latrines, hand soap, etc. It is expected that teachers who are in Elementary School Number 1 East Kuripan to enhance and encourage the knowledge and attitudes of students with PHBS in the school environment so they can understand and know the benefits for themselves and their environment. For further researchers, After the researcher completes this research, it is expected that further research related to clean and healthy living behaviors that may involve more independent variables. It also can be supported by laboratory test for some variables, for instance the hygiene and sanitation of food served in the school canteen.

\section{REFERENCES}

1. Kemendikbud. Data dan Statistik Pendidikan dan Kebudayaan 2017/2018 (Data and Statistic of Education and Culture). Jakarta; 2018.

2. Kemkes RI. Profil Kesehatan Indonesia Tahun 2013 (Health Profile of Indonesia in 2013). Jakarta; 2014.

3. Dinkes Lombok Barat. Profil Kesehatan Provinsi Nusa Tenggara Barat Tahun 2106 (Health Profile of West Nusa Tenggara Province in 2016). Lombok Barat, Nusa Tenggara Barat; 2016. 
4. Dinkes Lombok Barat. Profil Kesehatan Provinsi Nusa Tenggara Barat Tahun 2017 (Health Profile of West Nusa Tenggara Province in 2017). Lombok Barat, Nusa Tenggara Barat; 2017.

5. Notoatmodjo S. Promosi Kesehatan dan Ilmu Perilaku (Health Promotion and Behavioral Sciences). 1st ed. Jakarta: Rineka Cipta; 2007. 3 p.

6. Nurmahmudah E, Puspitasari T, Agustin IT. Perilaku Hidup Bersih dan Sehat ( PHBS ) pada Anak Sekolah (The Clean and Healthy Life Behavior Among School Students). J Abdimas UMTAS. 1(2):46-52.

7. Adriansayh AA, Firdausi NJ. Impelemntasi Perilaku Hidup Bersih dan Sehat (PHBS) dalam Membangun Gaya Hidup Sehat Sejak Dini di Sekolah Dasar Negeri (SDN) Lengkong 1, Desa Lengkong, Kecamatan Mojoanyar, Kabupaten Mojokerto (The Implementation of PHBS for Developt Early Healthy Life Style in Elementary School Number 1 Lengkong, Lengkong Village, Mojoanyar Sub-district, Mojokerto Regency) . J Univ Nahdlatul Ulama Surabaya. 2017;1(2):87-95.

8. Sirajuddin S, Masni, Najamuddin U. Peningkatan Praktek Gizi Seimbang dan PHBS pada Murid Sekolah Dasar (Improvement of Balanced Nutrition Practices and PHBS in Elementary School Students.). Media Gizi Pangan. 2018;25(2):13-9.

9. Tanjung N. Hubungan Pengetahuan dan Sikap Siswa Tentang Perilaku Hidup Bersih dan Sehat Dengan Tindakan PHBS di SD Swasta Luther Kecamatan Siatas Barita Tapanuli Utara Tahun 2013 (The Relationship between Students' Knowledge and Attitudes About Clean and Healthy Life Behavior in Luther Private Elementary School, Siatas Barita North Tapanuli District in 2013). J Mutiara Kesehatan Masyarakat. 2016;1(1):43-52.

10. Sulastri K, Purna IN, Suyasa IN. Hubungan Tingkat Pengetahuan dengan Perilaku Anak Sekolah Tentang Hidup Bersih dan Sehat di Sekolah Dasar Negeri Wilayah Puskesmas Selemadeg Timur II (The Relationship between the Level of Knowledge and the Behavior of School Children About Clean and Healthy Life Behavior in Elementary Schools in East Selemadeg Health Center II Working Area). J Kesehatan Lingkungan. 2014;4(1):99-106.

11. Istiarti T, Dangiran HL. Faktor-Faktor Yang Berhubungan Dengan Praktik Sanitasi Melalui Perilaku Hidup Bersih dan Sehat Pada Siswa Sekolah Dasar di Kecamatan Banyumanik (Factors Related to Sanitation Practices Through Clean and Healthy Life Behavior in Elementary School Students in Banyumanik District). J Kesehatan Lingkungan Indonesia. 2016;15(2):50-5.

12. Raharjo AS, Indarjo S. Hubungan Antara Pengetahuan, Sikap, dan Ketersediaan Fasilitas di Sekolah dalam Penerapan PHBS Membuang Sampah Pada Tempatnya (The Relationship Between Knowledge, Attitude, and Availability of Facilities in Schools in the Application of PHBS Disposing of Waste in Place). Unnes J Public Health. 2014;3(1):1-10.

13. Inayah R, Arfajah, Aini L. Pengaruh Pendidikan Kesehatan Terhadap Peningkatan 
Pengetahuan Tentang Perilaku Hidup Bersih Sehat (PHBS) Pada Siswa Sekolah Dasar Negeri 1 Serut Kecamatan Panti Kabupaten Jember (The Influence of Health Education on Increasing Knowledge of Healthy Clean Life Behavior (PHBS) in Elementary School Students 1 Serut, Panti District, Jember Regency). Indonesia J Health Science. 2018;137-40.

14. Mallo A, Sumira, Jaya N, Djalil. Nureani. Pengembangan Modul PHBS (perilaku hidup bersih dan sehat) Sekolah di SD Inpres BTN IKIP I Kota Makassar (Development of PHBS Module (clean and healthy life behavior) Schools in SD Inpres BTN IKIP I Makassar City). J Kebidanan Vokasional. 2019;4(2014):50-5.

15. Sondakh RS, Engkeng S, Tilaar CR. Hubungan Antara Pengetahuan dan Sikap dengan Tindakan Perilaku Hidup Bersih dan Sehat (PHBS) Sekolah pada Siswa Sekolah Dasar Negeri 112 Manado (The Relationship Between Knowledge and Attitudes with Clean and Healthy Life Behavior (PHBS) Schools in Manado 112 Elemetary School Students). 2015;

16. Sumiran RE, Maramis FRR, Pelealu FJO, Kesehatan F, Universitas M, Ratulangi S. Gambaran Perilaku Hidup Bersih dan Sehat (PHBS) Siswa Sekolah di SD Advent 01 Tikala Manado (Description of Clean and Healthy Life Behavior (PHBS) School Students at SD Advent 01 Tikala Manado). Universitas Sam Ratulangi;

17. Putri MA. Perilaku Hidup Bersih dan Sehat (PHBS) Anak di Panti Asuhan Al-Akbar Pekanbaru (Clean and Healthy Behavior (PHBS) of Children in Al-Akbar Orphanage Pekanbaru). JOM FISIP. 2017;4(2):1-14.

18. Vitriani E, Suryani D. Perilaku Hidup Bersih dan Sehat ( PHBS ) pada Anak Jalanan di Yayasan Rumah Impian Yogyakarta (Clean and Healthy Life Behavior (PHBS) on Street Children at Yogyakarta Dream House Foundation). J Berkala Kesehatan. 2019;5(2):45-52.

19. Lukas A, Utami NW, Putri RM. Hubungan Pengetahuan Ibu Dengan Perilaku Hidup Bersih dan Sehat (PHBS) Anak Pra Sekolah di TK Dharma Wanita Persatuan Tlogomas Malang (The Relationship between Mother's Knowledge and Clean and Healthy Life Behavior (PHBS) of Pre-School Children in Dharma Wanita Kindergarten Tlogomas Malang). Nurse News (Meriden). 2019;4(1):219-28.

20. Sanjaya R, Fara YD, Sagita YD. Pendidikan Perilaku Hidup Bersih dan Sehat (PHBS) di Sekolah (Education of Clean and Healthy Life Behavior (PHBS) in Schools). J Pengabdian Kpd Masy Ungu (ABDI KE UNGU). 1(1):55-60.

21. Karaeng VD, Umboh JML, Akili RH. Gambaran Perilaku Hidup Bersih dan Sehat (PHBS) Pada Siswa Sekolah Dasar Negeri Inpres Karatung Kecamatan Manganitu Kabupaten Sangihe (Overview of Clean and Healthy Life Behavior (PHBS) in Karatung Inpres Elementary School Students Manganitu Sub-district Sangihe District). :81-8.

22. Lina H putri. Perilaku Hidup Bersih dan Sehat (PHBS) Siswa di SDN 42 Korong Gadang Kecamatan Kuranji Padang (Clean and Healthy Life Behavior (PHBS) Students at SDN 42 
Korong Gadang, Kuranji District, Padang). J Promkes. 2016;4(1):92-103.

23. Prasetya RA, Santoso W, Zakiyah A. Gambaran Perilaku Hidup Bersih dan Sehat (PHBS) Siswa Siswi di SMKN 1 Mojoanyar Mojokerto (Overview of Clean and Healthy Life Behavior (PHBS) Students at SMK 1 Mojoanyar Mojokerto). J S1 Keperawatan STIKES Bina Sehat. $: 1-9$.

24. Wawan A, Dewi M. Teori dan Pengukuran Pengetahuan, Sikap, dan Perilaku Manusia (Theory and Measurement of Human Knowledge, Attitudes, and Behavior). Yogyakarta: Nuha Medika; 2010.

25. Gabur MGJ, Yudiernawati A, Dewi N. Hubungan Perilaku Hidup Bersih dan Sehat (PHBS) Terhadap Personal Hygiene Anak Usia Sekolah di SDN Tlogomoas 2 Malang (Relationship of Clean and Healthy Life Behavior (PHBS) to Personal Hygiene of School Age Children at SDN Tlogomoas 2 Malang). Nurse News (Meriden). 2017;2(1):533-42.

26. Renaldi. Hubungan Pengetahuan dan Sikap Siswa tentang Perilaku Hidup Bersih dan Sehat dengan Tindakan PHBS di SD Kalasan Sleman Yogyakarta (The Relationship between Students' Knowledge and Attitudes about Clean and Healthy Life Behavior Actions at Kalasan Sleman Elementary School, Yogyakarta). J Kesehatan Masyarakat. 2015;2(3):52.

27. Harrington J, Perry IJ, Lutomski J, Fitzgerald AP, Shiely F, Mcgee H, et al. Living longer and feeling better: healthy lifestyle, self-rated health, obesity and depression in Ireland. Eur $\mathbf{J}$ Public Health. 2009;20(1):91-5.

28. Ni'mah AU. Hubungan Perilaku Hidup Bersih dan Sehat (PHBS) serta Kebiasaan Jajajn Dengan Kejadian Diare pada Siswa di SDN 1 Kemiri, Boyolali (Relationship between Clean and Healthy Life Behavior (PHBS) and the Habit of Snacking with the Incidence of Diarrhea among Students at SDN 1 Kemiri, Boyolali). Universitas Muhammadiyah Surakarta; 2019.

29. Saputro W, Budiarti LY, Herawati. Perilaku Hidup Bersih dan Sehat (PHBS) dengan Kejadian Diare pada Anak Sekolah Dasar (SD) (Clean and Healthy Life Behavior (PHBS) with the Incidence of Diarrhea in Elementary School Children). DK Perilaku Hidup Bersih dan Sehat. 2013;01(01):40-7.

30. Julianti R, Nasirun M, Wembrayarli. Pelaksanaan Perilaku Hidup Bersih dan Sehat (PHBS) di Lingkungan Sekolah (Implementation of Clean and Healthy Behavior (PHBS) in the School Environment). J Ilmu Potensia. 2018;3(2):11-7.

31. Notoadmodjo S. Metode Penelitian Kesehatan (Health Research Methods). Jakarta: Rineka Cipta; 2012. 125 p.

32. Diana FM, Susanti F, Irfan A. Pelaksanaan Program Perilaku Hidup Bersih dan Sehat (PHBS) di SD Negeri 001 Tanjung Balai Karimun (The Implementation of the Clean and Healthy Life Behavior Program (PHBS) in 001 Tanjung Balai Karimun Elementary School). J Kesehatan Masyarakat. 2014;8(1):46-51. 
33. Murwaningsih A. Ilmu Keperawatan Komunitas 2 (Community Nursing 2). Jakarta: Sagung Seto; 2016. 